\title{
Effect of Hyperthermia on the Transcription Rate of Heat-Shock Genes in the Rabbit Cerebellum and Retina Assayed by Nuclear Run-Ons
}

\author{
Cheryl A. D'Souza, Sheila J. Rush, and Ian R. Brown* \\ Department of Zoology, University of Toronto, Scarborough Campus, Ontario, Canada
}

The induction of heat-shock protein 70 (hsp70) mRNA in the hyperthermic rabbit brain has been examined previously by using Northern blotting and in situ hybridization procedures that measure steady-state levels of mRNA, which may be influenced by transcript stability and transcription rate. In the present investigation, the in vivo transcription rate of hsp70 has been examined by using run-on transcription assays on isolated brain nuclei. A major up-regulation in the transcription rate of hsp70 was observed between 0.75 and 1.50 hours after hyperthermia in the cerebellum and the retina. Gel-mobility shift assays revealed that the time course of conversion of heatshock transcription factor (HSF1) to a DNA-binding form paralleled the transcriptional induction profile of hsp70. The transcription rates of several nonheatshock genes were also studied in the hyperthermic brain, and little change was noted relative to the induction of hsp70. Thus, a physiologically relevant increase in temperature of $2.5^{\circ} \mathrm{C}$ induces a major up-regulation in the in vivo transcription rate of hsp70 in the nervous system with little affect on the transcription rates of other genes. J. Neurosci. Res. 52:538-548, 1998. 1998 Wiley-Liss, Inc.

Key words: heat-shock protein 70; heat-shock protein 90; run-on transcription assay

\section{INTRODUCTION}

In response to various forms of stress, cells induce the synthesis of heat-shock proteins (hsps). These conserved proteins function in repair and protective processes to help ensure cellular survival (Georgopoulos and Welch, 1993; Mayer and Brown, 1994; Morimoto et al., 1994). Classification of hsps is based on the molecular weight of these stress proteins (for example, hsp90, hsp70, hsp60). Hsp70 belongs to a multigene family, and both constitutive (hsc70) and stress-inducible (hsp70) members exist (Lindquist and Craig, 1988; Welch, 1992).
In eukaryotes, the heat-shock response is mediated by the binding of a heat-shock transcription factor (HSF) to conserved DNA sequences known as heat-shock elements (HSEs; Morimoto, 1993; Lis and Wu, 1993; $\mathrm{Wu}, 1995)$. In mammalian cells, at least three factors have been identified, HSF1, HSF2, and HSF4 (Rabindran et al., 1991; Sarge et al., 1991; Schuetz et al., 1991; Nakai et al., 1997). HSF1 is thought to play a role in the stress-induced transcription of heat-shock genes (Baler et al., 1993; Sarge et al., 1993). The activation of HSF1 is a multistep pathway involving trimerization of the factor, acquisition of DNA-binding, and, in some cells, hyperphosphorylation (Baler et al., 1993; Rabindran et al., 1993; Sarge et al., 1993; Cotto et al., 1996; Xia and Voellmy, 1997).

The present study investigates the time course of in vivo transcriptional activation of heat-shock genes in regions of the rabbit nervous system following a feverlike increase in body temperature of $2.5^{\circ} \mathrm{C}$. Previous work in our laboratory has examined the induction of heat-shock genes in the hyperthermic rabbit brain by using Northern blotting and in situ hybridization methods (Brown and Rush, 1990; Manzerra et al., 1993; Foster and Brown, 1996a). These procedures measure steadystate levels of mRNA that may be influenced by transcript stability and transcription rate.

In the present investigation, run-on transcription assays with isolated brain nuclei were employed to measure the in vivo rate of transcriptional activity. Results demonstrate that a physiologically relevant temperature increase of $2.5^{\circ} \mathrm{C}$ causes a major up-regulation in the in vivo transcription rate of heat-shock genes in the nervous system of an intact, thermoregulating mammal.

Contract sponsor: MRC Canada.

*Correspondence to: I.R. Brown, Department of Zoology, University of Toronto, Scarborough Campus, West Hill, Ontario, Canada, M1C $1 \mathrm{~A} 4$.

Received 2 October 1997; Revised 16 December 1997; Accepted 15 January 1998 
In addition, the time course of this transcriptional induction parallels the DNA-binding activity of HSF1. The transcription rates of several nonheat-shock genes were relatively unaffected during the phase of hsp70 induction.

\section{MATERIALS AND METHODS}

\section{Induction of Hyperthermia}

Body temperature of male New Zealand white rabbits (average weight $1.8 \mathrm{~kg}$ ) was elevated $2.5^{\circ} \mathrm{C}$ above normal by the intravenous injection of $100 \mu \mathrm{g} / \mathrm{kg}$ d-lysergic acid diethylamide (LSD), as described previously (Cosgrove and Brown, 1983). Previous work has shown that the induction of hsp70 mRNA in the rabbit brain is due to the hyperthermic effects of this drug (Manzerra and Brown, 1990). Rabbit body temperature was monitored by using a rectal thermistor probe. It has been shown that rectal temperature is an accurate representation of body temperature of organs in rabbits and that rectal and organ temperatures increase in parallel during hyperthermia (Kluger et al., 1973; Baker, 1979). Animals were killed by cervical dislocation at specific time intervals after drug injection $(0.75 \mathrm{hr}, 1.00 \mathrm{hr}, 1.50 \mathrm{hr}, 2.00 \mathrm{hr}$, and $5.00 \mathrm{hr})$. The protocol used for the treatment of animals was approved by the Animal Care Committee of the University of Toronto.

\section{Plasmids}

For the nuclear run-on transcription assays of heat-shock genes, four plasmids were used. The subclone pHA7.6, a 600-base-pair (bp) EcoRI fragment from the human constitutive hsc70-related protein p72 in pGEM2, was obtained from R. Morimoto (Watowich and Morimoto, 1988). The subclone $\mathrm{pH} 2.3$, a 2.3 -kb HindIIIBamHI fragment of the human hsp70-inducible gene in pGEM1, was obtained from R. Morimoto (Wu et al., 1985). An 843-bp insert was digested out with ClaI and HindIII and subcloned into the vector pSP72. Hsp90 $\alpha$ and hsp $90 \beta$ cDNA plasmids, which were obtained from Dr. L. Weber (Hickey et al., 1989; Rebbe et al., 1989), contained a $1.4-\mathrm{kb}$ partial insert and a $2.1-\mathrm{kb}$ full-length insert of hsp $90 \alpha$ and hsp $90 \beta$ coding sequences, respectively. For hsp90 $\alpha$, a 700-bp insert from the 3 '-coding region was digested out of the cDNA plasmid with BclI and HindIII and subcloned into a pSP72 vector. For hsp90ß, a 701-bp insert from the 3 '-coding region was digested out of the cDNA plasmid with HindIII and BamHI and subcloned into a pSP72 vector.

For the run-on transcription assays of nonheatshock genes, the following DNA probes were used: a 3.5-kb rat calmodulin (CaM I) cDNA insert in pHG327 (Ni et al., 1992); a 2.4-kb rat neuron-specific enolase (NSE) cDNA insert in pBlueScript (Forss-Petter et al.,
1986), a 1.09-kb mouse neurofilament-L (NFL) genomic DNA insert in pGEM3Z (Lewis and Cowan, 1986), a 743-bp rat cyclophilin cDNA insert in pGEM3Z (1B15; Danielson et al., 1988), and a 2.67-kb rat SC1 cDNA insert in pHG327 (Johnston et al., 1990). cDNA plasmids were linearized with restriction enzymes, denatured in $100 \mathrm{mM} \mathrm{NaOH}$ at room temperature, and neutralized in $6 \times$ standard saline citrate (SSC). DNA $(5 \mu \mathrm{g})$ was spotted onto nitrocellulose filters by using a dot-blot apparatus (Schleicher and Schuell, Keene, NH). Filters were air dried overnight and baked for $2 \mathrm{hr}$ at $80^{\circ} \mathrm{C}$ under vacuum.

\section{Isolation of Nuclei}

Neural regions (cerebellum and retina) were dissected out and homogenized in $20 \mathrm{ml}$ of lysis buffer (10 $\mathrm{mM} \mathrm{NaCl} ; 3 \mathrm{mM} \mathrm{MgCl} 2 ; 10 \mathrm{mM}$ Tris, $\mathrm{pH} \mathrm{7.4;0.5 \%}$ NP-40). Homogenates were spun at 2,500 rpm for $5 \mathrm{~min}$ in an IEC clinical centrifuge (International Equipment Corp., Needham Heights, MA) at $4^{\circ} \mathrm{C}$. The supernatant was discarded, and the nuclear pellet was resuspended in storage buffer (40\% glycerol; $50 \mathrm{mM}$ Tris, $\mathrm{pH} 8.0 ; 5 \mathrm{mM}$ $\mathrm{MgCl}_{2} ; 0.1 \mathrm{mM}$ EDTA). Aliquots of $200 \mu \mathrm{l}$ were frozen on dry ice and stored at $-70^{\circ} \mathrm{C}$.

\section{Nuclear Run-On Transcription Assay}

Assays were performed according to Greenberg and Bender (1992). Nuclear run-on transcription assays have been used previously in tissue culture systems to examine transcription rates of heat-shock genes (Mathur et al., 1994). Aliquots of isolated nuclei (400 $\mu \mathrm{g}$ DNA for cerebellum and $120 \mu \mathrm{g}$ DNA for retina) were incubated with $200 \mu \mathrm{l}$ of a solution containing $10 \mathrm{mM}$ Tris, $\mathrm{pH}$ 8.0; $5 \mathrm{mM} \mathrm{MgCl} 2 ; 0.3 \mathrm{M} \mathrm{KCl} ; 5 \mathrm{mM}$ DTT; $1 \mathrm{mM}$ each of ATP, $\mathrm{CTP}$, and GTP; and $100 \mu \mathrm{Ci}$ of $\left[\alpha^{-32} \mathrm{P}\right]$ uridine triphosphate (UTP; $3,000 \mathrm{Ci} / \mathrm{mmol}$ ) for $30 \mathrm{~min}$ at $30^{\circ} \mathrm{C}$. Labelled RNA transcripts were isolated by phenol extraction and TCA precipitation. Equal cpm were hybridized to $5 \mu \mathrm{g}$ of filter-bound linearized and denatured plasmid cDNA at $65^{\circ} \mathrm{C}$ for $40 \mathrm{hr}$. Filters were washed in $2 \times \mathrm{SSC}$ at $55^{\circ} \mathrm{C}$ for $2 \mathrm{hr}$ and were set up for autoradiography for 1 week. Data are representative of two or three independent experiments carried out on tissue isolated from three different sets of animals.

\section{Gel-Mobility Shift Assays}

Portions of cerebellar and retinal tissue from the same animals that were used for nuclear isolation were dissected out and frozen on dry ice. Tissue samples were homogenized in 5 volumes of homogenization buffer (20 $\mathrm{mM}$ HEPES, $\mathrm{pH} 7.9 ; 420 \mathrm{mM} \mathrm{NaCl} ; 25 \%$ glycerol; 1.5 $\mathrm{mM} \mathrm{MgCl} 2 ; 0.2 \mathrm{mM}$ EDTA; $0.5 \mathrm{mM}$ dithiothreitol; 0.5 $\mathrm{mM}$ phenylmethylsulfonyl fluoride; $10 \mu \mathrm{g} / \mathrm{ml}$ leupeptin; 


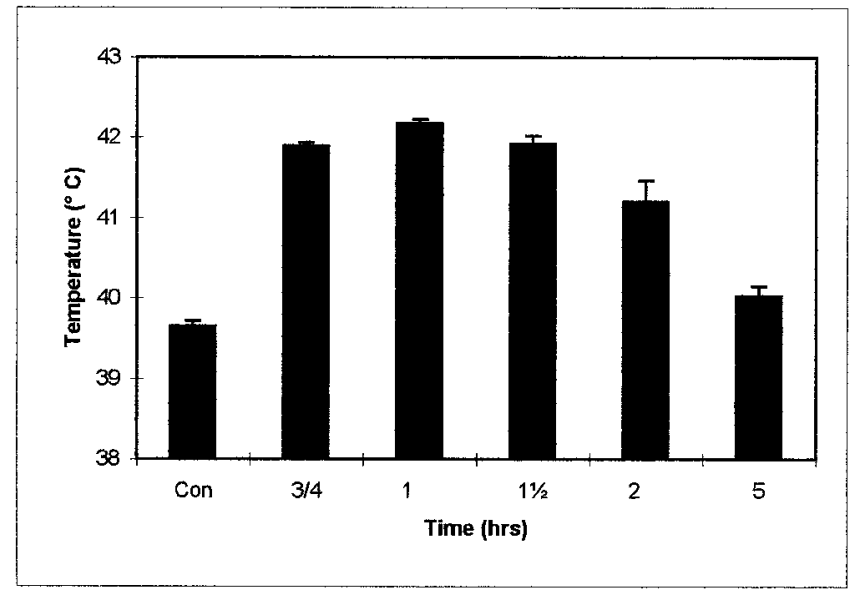

Fig. 1. Time course of hyperthermia. Rabbits were exposed to a transient, physiologically relevant increase in temperature of $2.5^{\circ} \mathrm{C}$. Body temperature was measured by using a rectal thermistor probe. Three animals were used per time point. Con, control.

$10 \mu \mathrm{g} / \mathrm{ml}$ pepstatinA; and $10 \mu \mathrm{g} / \mathrm{ml}$ aprotinin), as described previously (Sarge et al., 1994; Brown and Rush, 1996). Following homogenization, extracts were microfuged at $12,000 \times \mathrm{g}$ for 2 minutes at $4^{\circ} \mathrm{C}$. The supernatant was drawn off and frozen in 50- $\mu \mathrm{l}$ aliquots on dry ice. Aliquots were stored at $-70^{\circ} \mathrm{C}$. Gel-mobility shift assays on $4 \%$ nondenaturing polyacrylamide gels were carried out as described by Sarge et al. (1991), by using a synthetic, self-complementary HSE oligonucleotide (5'-CTAGAAGCTTCTAGAAGCTTCTAG-3'). The HSE probe was end labelled with T4 polynucleotide kinase and $\left[\gamma_{-}{ }^{32} \mathrm{P}\right]$ ATP. Thirty micrograms of protein were incubated with $50,000 \mathrm{cpm}$ of HSE probe for $20 \mathrm{~min}$ at room temperature. For gel-supershift experiments, tissue extracts were preincubated with HSF1 or HSF2 polyclonal antibodies prior to gel-mobility shift analysis. Antibodies were donated by Kevin Sarge (University of Kentucky) and Richard Morimoto (Northwestern University).

\section{RESULTS}

\section{Time Course of Hyperthermia}

The body temperature of rabbits was elevated transiently $2.5^{\circ} \mathrm{C}$ above normal, as described previously (Cosgrove and Brown, 1983). Animals reached a maximum temperature at $0.75-1.50 \mathrm{hr}$ and returned to normal temperature by $5.00 \mathrm{hr}$ (Fig. 1). The temperature increment experienced by the animals $\left(2.5^{\circ} \mathrm{C}\right)$ is physiologically relevant, because it is similar to that attained during fever and inflammation reactions (Saper and Breder, 1994). Earlier studies in our laboratory have demonstrated that this temperature increment is sufficient to induce hsp70 mRNA and protein in the rabbit brain, as measured by Northern blotting, in situ hybridization, Western blotting, and immunocytochemical methods (Manzerra et al., 1993, 1997; Foster et al., 1995; Foster and Brown, 1996b).

\section{Transcriptional Induction of Heat-Shock Genes in Regions of the Rabbit Nervous System Following Hyperthermia}

To examine the effect of a physiologically relevant increase in body temperature of $2.5^{\circ} \mathrm{C}$ on the in vivo transcription rate of heat-shock genes, run-on transcription assays were carried out on nuclei isolated from regions of the rabbit nervous system. In the cerebellum (Fig. 2), the in vivo transcription rate of hsp70 was observed to increase 22-fold relative to control levels. Following a plateau at $0.75-1.50 \mathrm{hr}$, transcriptional induction decreased at $2.00 \mathrm{hr}$ and returned to control levels by $5.00 \mathrm{hr}$. Thus, the time course of changes in the in vivo transcription rate of hsp70 in the cerebellum appeared to follow the profile of alteration in rabbit body temperature observed in Figure 1. Up-regulation of the transcription rates of hsp90 $\alpha$ and hsp90 $\beta$ followed a similar time course to that observed for hsp70; however a lower magnitude of induction was apparent (Fig. 2A). Changes in the transcription rate of hsc70 were affected only slightly. The nonheat-shock gene cyclophilin (1B15) did not show induction. Lack of signal with the vector DNA indicated that nonspecific binding was minimal.

Compared with the cerebellum, a greater magnitude of hsp70 transcriptional induction was seen in the retina (Fig. 3A). The in vivo transcription rate of hsp70 peaked at $1.50 \mathrm{hr}$, with a 130 -fold increase relative to control values, and returned to basal levels by $5.00 \mathrm{hr}$ (Fig. 3B). Similar to the cerebellum, the transcription rate of hsp $90 \alpha$ and hsp90 $\beta$ showed a lower magnitude of induction compared with that observed for hsp70. In the retina, the peak hsp70 transcription rate was somewhat delayed relative to the time course of rabbit body temperature (compare Fig. 1 with Fig. 3B).

\section{Time-Course Analysis of the Activation of HSF in Rabbit Neural Regions Following Hyperthermia}

Figures 2 and 3 show that a physiologically relevant increase in body temperature of $2.5^{\circ} \mathrm{C}$ was sufficient to induce a major up-regulation in the in vivo transcription rate of hsp70. Previous work in our laboratory has demonstrated that this temperature increment is also sufficient to induce the conversion of HSF to a DNAbinding form (Brown and Rush, 1996). Gel-mobility shift assays were carried out on extracts from rabbit neural regions isolated from the same animals that were used in the nuclear run-on analysis. 
A

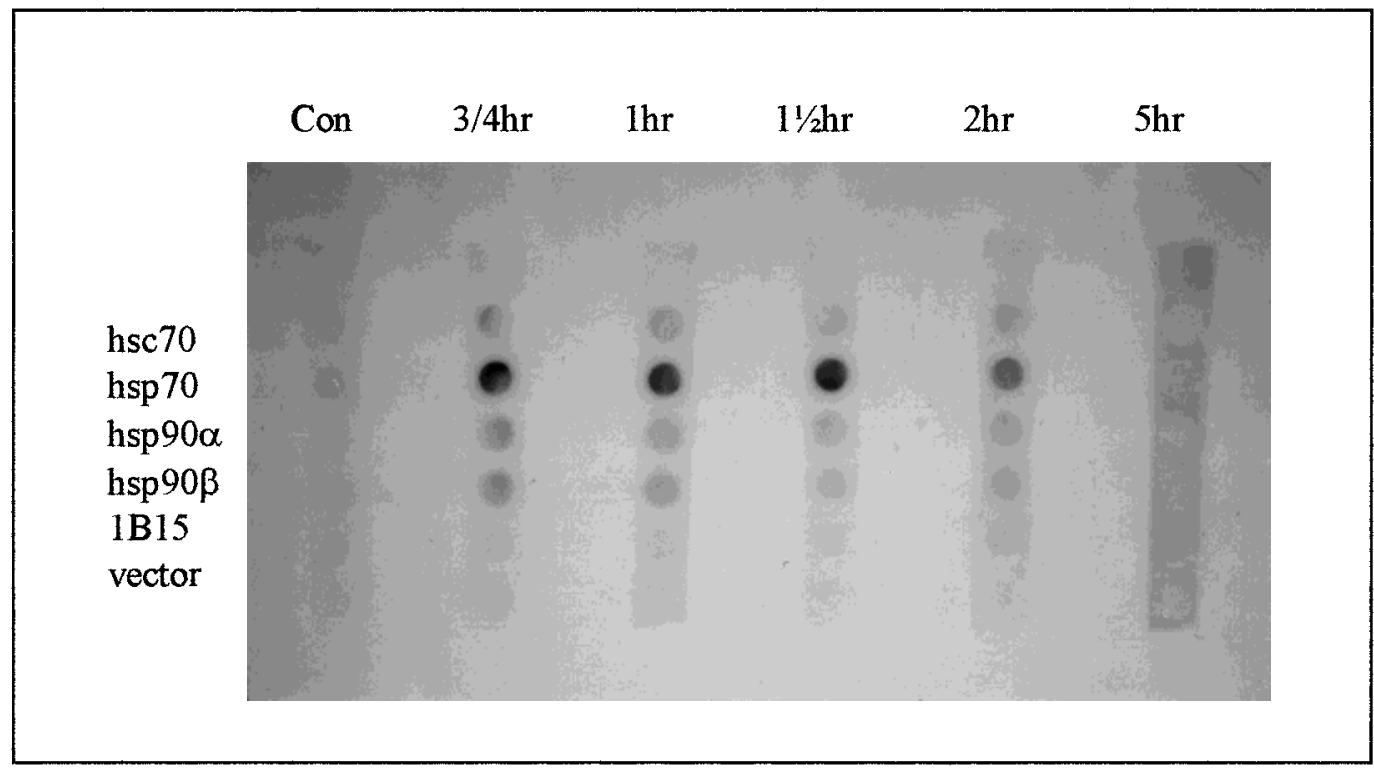

B

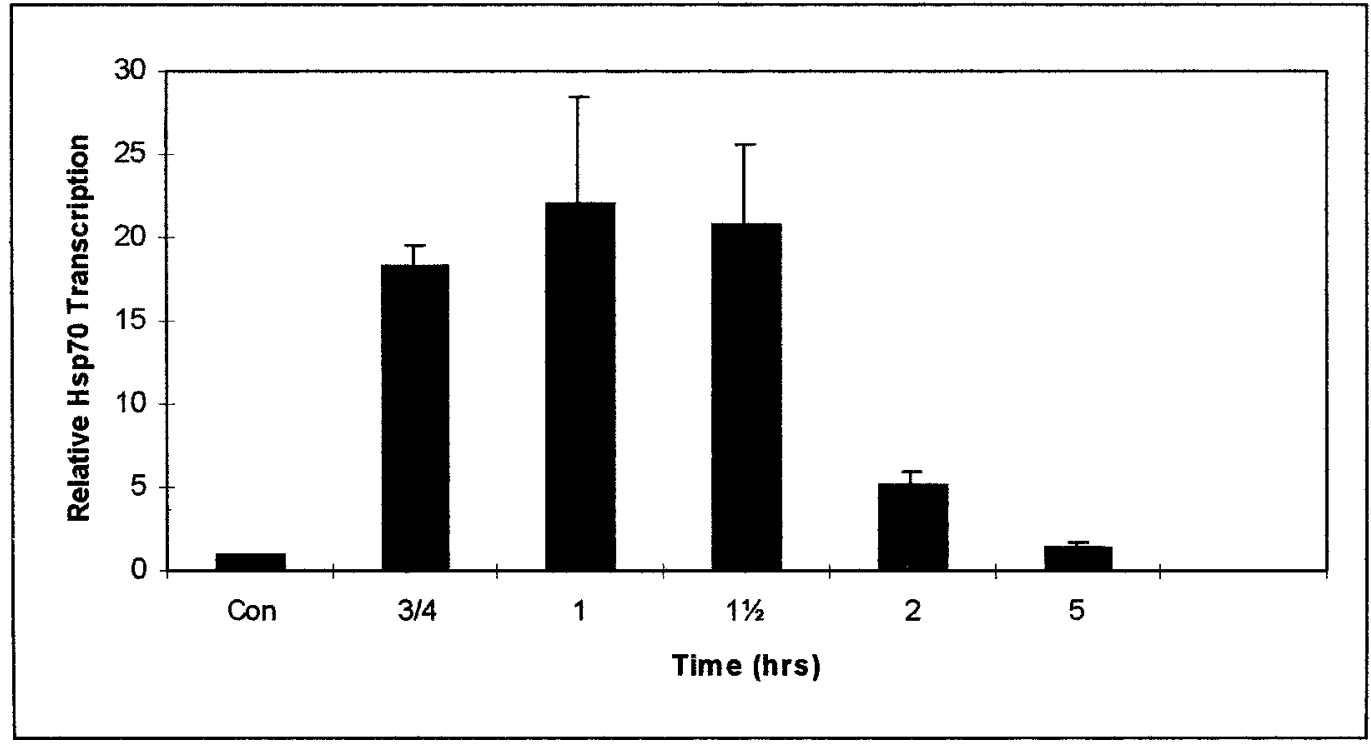

Fig. 2. Transcription rate of heat-shock genes in the cerebellum following physiologically relevant hyperthermia. Nuclear run-on transcription assays were performed on rabbit cerebellar nuclei isolated from control animals and at various time points following hyperthermia. Labelled RNA transcripts were hybridized to $5 \mu \mathrm{g}$ of cDNA plasmids, which were fixed onto nitrocellulose filters. A: Autoradiogram showing transcription rates of heat-shock genes (hsc70, hsp70, hsp90 $\alpha$, hsp90ß) as well as cyclophilin (1B15). Vector DNA was used as a negative control. B: Transcription of hsp70 shown in A was quantitated by using an imaging densitometer. Control values (Con) were standardized to 1.0. Data represent independent experiments carried out on tissue from three different sets of animals. 


\section{A}

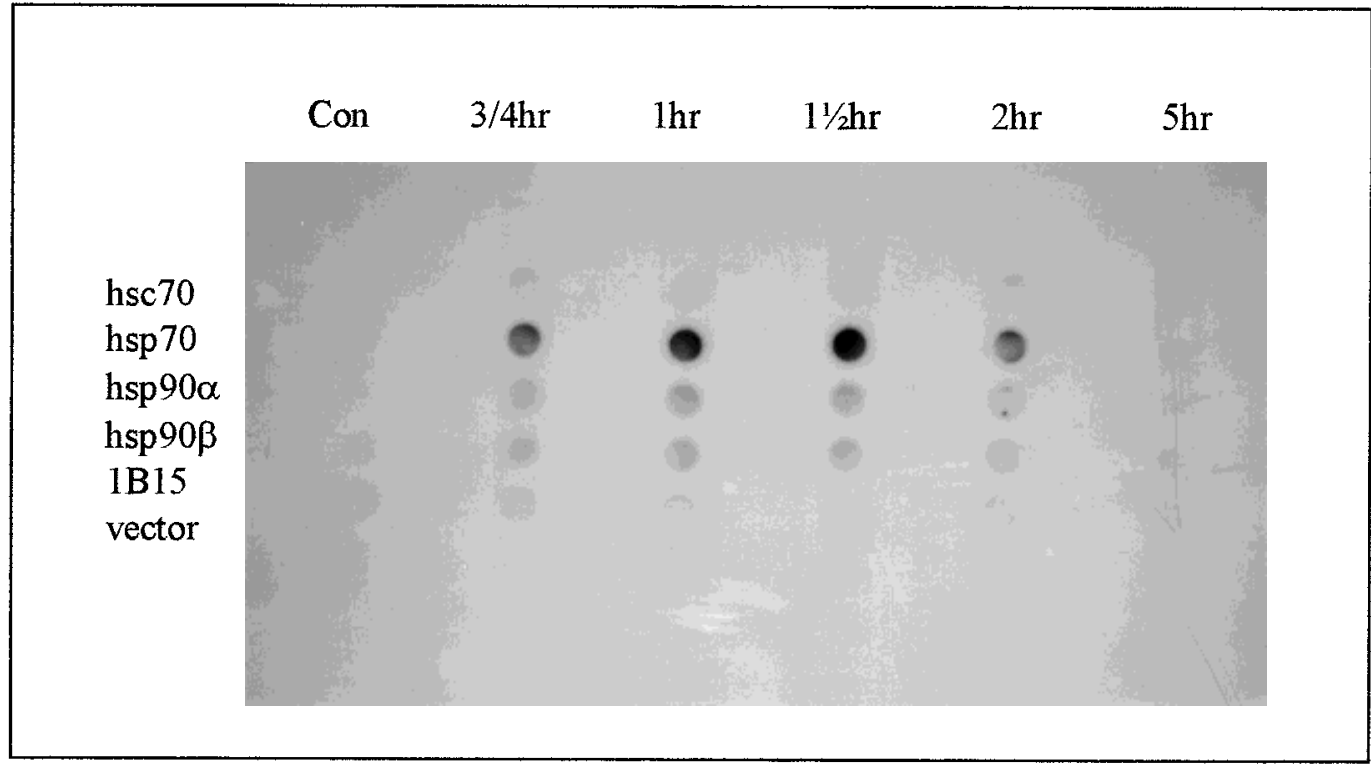

\section{B}

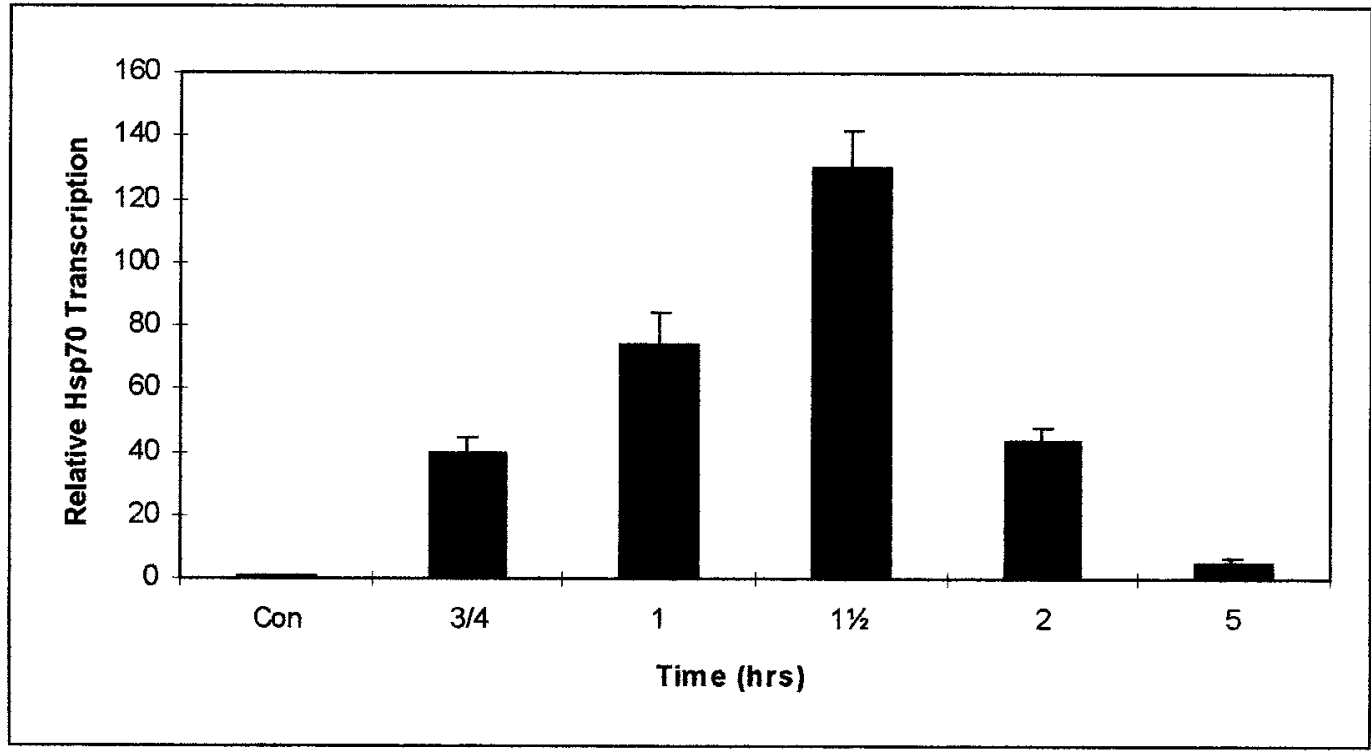

Fig. 3. Transcription rate of heat-shock genes in the retina following hyperthermia. Retinal nuclei isolated at various time points following hyperthermia were used to carry out nuclear run-on transcription assays. A: Autoradiogram of transcription rates of heat-shock genes (hsc70, hsp70, hsp90 $\alpha$, hsp90ß) as well as cyclophilin (1B15). B: Quantitation of the hsp70 transcription rate observed following hyperthermia. Data represent independent experiments carried out on tissue from three different sets of animals. Con, control. 
In the cerebellum (Fig. 4), induction of HSEbinding activity was detected at $0.75 \mathrm{hr}$ and remained high until $2.00 \mathrm{hr}$. At $5.00 \mathrm{hr}$, HSE-binding was comparable to control levels. Thus, conversion of HSF to a DNA-binding form paralleled the time course of upregulation of the in vivo transcription rate of hsp70 that was observed in the nuclear run-on analysis (Fig. 2). Both revealed a plateau from $0.75 \mathrm{hr} 1.50 \mathrm{hr}$, with a return to control values by $5.00 \mathrm{hr}$. Gel-shift experiments performed on extracts from the retina (Fig. 5) revealed DNA-binding activity that reached a maximum at $1.50 \mathrm{hr}$. This profile paralleled the time course of up-regulation of the hsp70 transcription rate that was observed in the retina by the nuclear run-on assays (Fig. 3).

\section{Characterization of the HSE-Binding Activity}

To determine whether the HSE-binding activity observed in Figures 4 and 5 was due to the binding of HSF1 or HSF2, gel-supershift experiments were performed. Cerebellar extracts from 1-hr hyperthermic animals were preincubated with antibodies specific to either HSF1 or HSF2 before gel-mobility shift analysis (Fig. 6). In contrast to the HSF2 antibody, the HSF1 antibody supershifted the HSF:DNA complex seen in lane 1, indicating that HSE-binding activity resulted from the activation of HSF1 and not HSF2 (Fig. 6). In the last two lanes, extracts were preincubated with either a 200-fold or a 400-fold excess of unlabelled HSE probe. Excess cold HSE competed out protein binding, demonstrating specificity of the probe.

\section{Transcriptional Activity of Nonheat-Shock Genes in Rabbit Neural Regions}

Nuclear run-on transcription assays were used to investigate the effect of a fever-like increase in body temperature of $2.5^{\circ} \mathrm{C}$ on the in vivo transcription rate of nonheat-shock genes: CaM I (Ni et al., 1992), NSE (Forss-Petter et al., 1986), NFL (Lewis and Cowan, 1986), 1B15 (Danielson et al., 1988), and SC1 (Johnston et al., 1990), a putative extracellular matrix glycoprotein. In the cerebellum (Fig. 7) an up-regulation was noted in the in vivo transcription rate of hsp70 similar to that shown in Figure 2; however, the nonheat-shock genes demonstrated comparatively little change in transcription rate throughout the time course of heat shock. Thus, although a physiologically relevant temperature increase of $2.5^{\circ} \mathrm{C}$ is sufficient to induce a major up-regulation in the in vivo transcription rate of hsp70, other nonheatshock genes appear to be relatively unaffected.

\section{DISCUSSION}

Previous studies in our laboratory have examined the expression of hsp70 mRNA after hyperthermia. By

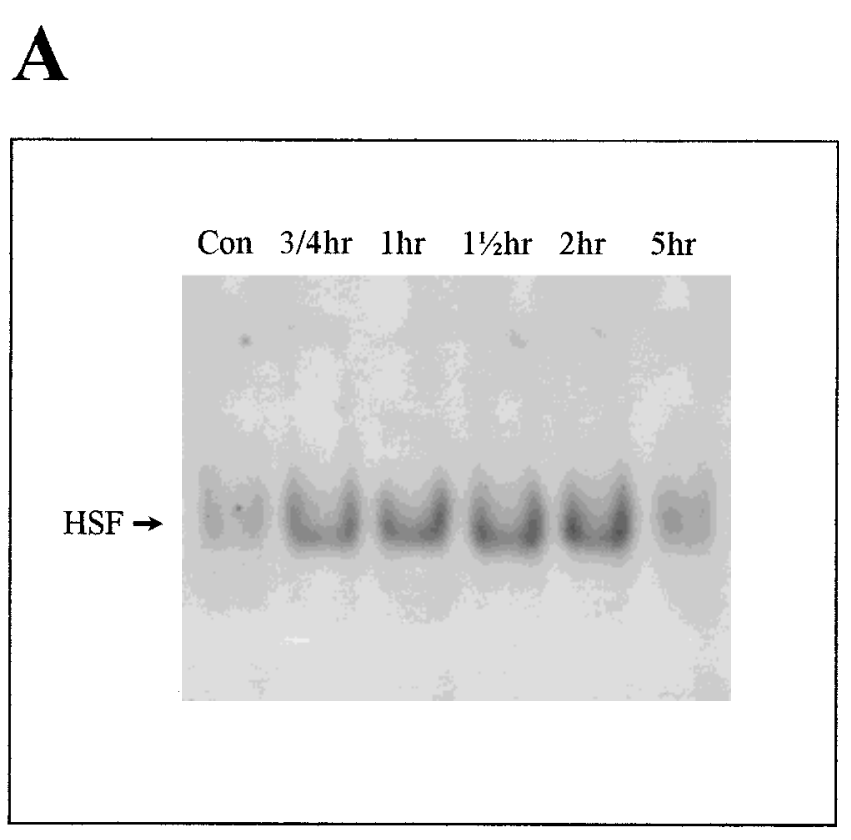

\section{B}

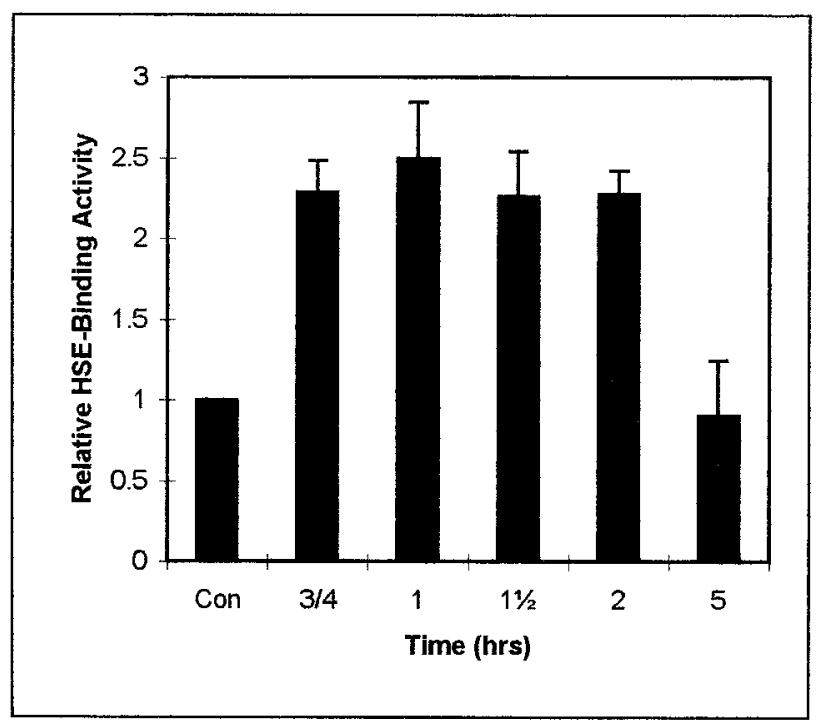

Fig. 4. Gel-mobility shift analysis of heat-shock element (HSE)-binding activity in rabbit cerebellum following hyperthermia. Gel-mobility shift assays were performed on cerebellar extracts isolated from control animals and at various time points following hyperthermia. These experiments were carried out by using a ${ }^{32} \mathrm{P}$-labelled synthetic HSE oligonucleotide. The probe contained four inverted repeats of the HSE consensus sequence 5'-AGAAN-3'. A: Autoradiogram showing HSE-binding activity. B: Quantitation of the gel-shift signal. Control values (Con) were standardized to 1.0. Data represent independent experiments carried out on tissue isolated from three sets of animals. 


\section{A}

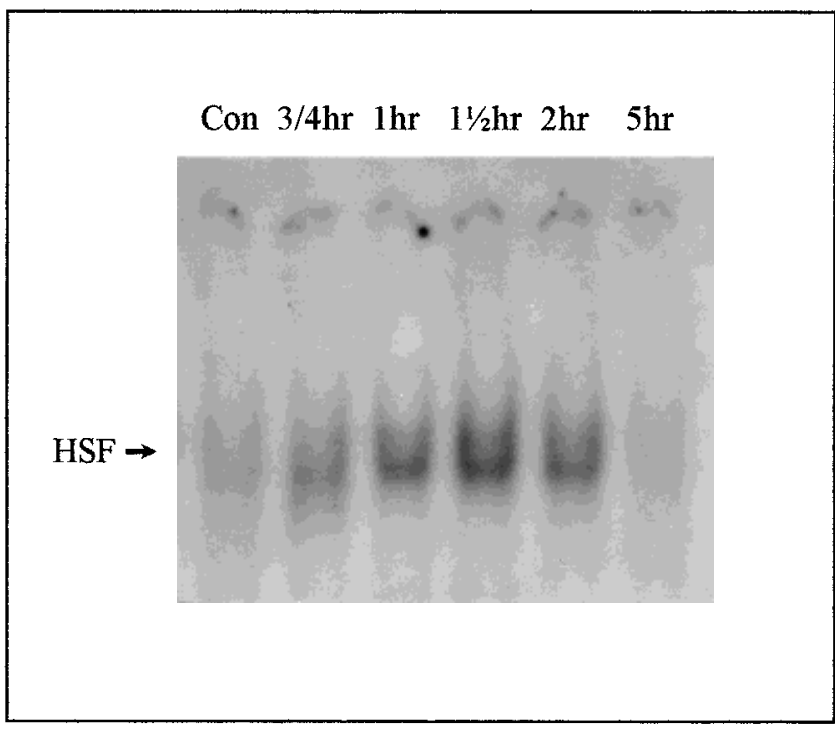

B

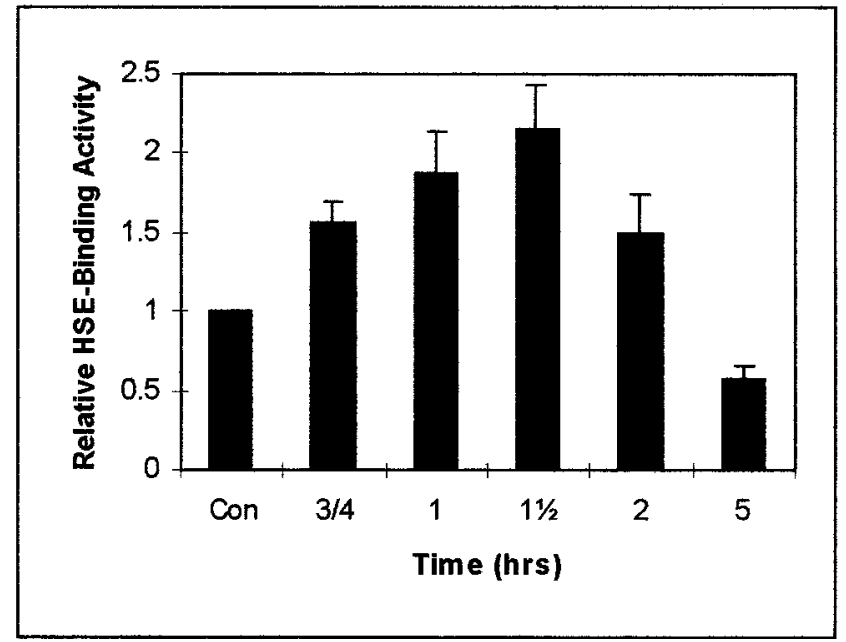

Fig. 5. Gel-mobility shift analysis of HSE-binding activity in the rabbit retina following hyperthermia. Extracts isolated from the retina were used in gel-shift experiments to analyze the time course of heat-shock transcription factor (HSF) activation following hyperthermia. A: Autoradiogram of HSE-binding activity. B: The gel-shift signal was quantitated by using an imaging densitometer. Data represent independent experiments carried out on tissue from three sets of animals. Con, control.

using Northern blotting and in situ hybridization, induction of hsp70 mRNA was observed in 1-hr hyperthermic rabbit neural regions (for review, see Brown, 1994).
These studies examined the steady-state levels of hsp70 mRNA transcripts; therefore, they did not distinguish between changes in mRNA stability/turnover or changes in the transcription of the genes.

A convenient method for monitoring transcription rates of different genes is the nuclear run-on transcription assay. However, previous investigators have used this technique in tissue culture systems (Abravaya et al., 1991; Vazquez et al., 1993; Mathur et al., 1994; Sistonen et al., 1994), and the procedure has not been applied previously to nuclei isolated from neural tissue in vivo. In these in vitro systems, temperature increases of $5^{\circ} \mathrm{C}$ or more are usually employed to heat shock the tissue culture cells and obtain transcriptional activation of hsp70. These temperature increments are supraphysiological, and, if they are used in the intact organism, the animal will not survive. In this report, we have adapted the nuclear run-on transcription assay to our in vivo neural system. This required the rapid isolation of brain nuclei from small amounts of neural tissue, using NP-40 detergent to lyse the cell membrane. Our results show that a small temperature increase $\left(2.5^{\circ} \mathrm{C}\right)$ in an intact, thermoregulating mammal induces a major up-regulation in the in vivo transcription rate of hsp70. This temperature increment is similar to that attained during fever reactions and, thus, is physiologically relevant.

In the cerebellum, nuclear run-on transcription assays showed that the up-regulation in the transcription rate of hsp70 plateaued between $0.75 \mathrm{hr}$ and $1.50 \mathrm{hr}$ after heat shock. Previous work in our laboratory has shown that several cell types in the cerebellum accumulate hsp70 mRNA following hyperthermia (Bergmann glia, granule neurons, and glia of the deep white matter; Manzerra and Brown, 1992; Foster et al., 1995). Thus, the broad plateau observed in the cerebellum probably represents induction by several cell types.

In contrast to the cerebellum, the transcriptional profile for hsp70 in the retina peaked at $1.50 \mathrm{hr}$ (Fig. 3). Tytell et al. (1994) have shown that the main cell type in the rat retina that induces hsp70 after hyperthermia is the photoreceptor. Thus, time-course differences in hsp70 transcription between the cerebellum and the retina may reflect differences in cell populations that induce hsp70. Time-course differences in hsp70 may also be indicative of differences in temperature. It has been shown in rabbits that rectal temperature and organ temperature increase in parallel during hyperthermia (Kluger et al., 1973; Baker, 1979). Thus, the colonic temperature reflects the temperature of the cerebellum. Indeed, the transcription of hsp70 in the cerebellum parallels the profile of rabbit body temperature during hyperthermia (see Figs. 1, 2). However, the eye may dissipate heat to the external environment; hence, the retina may require a longer period of 


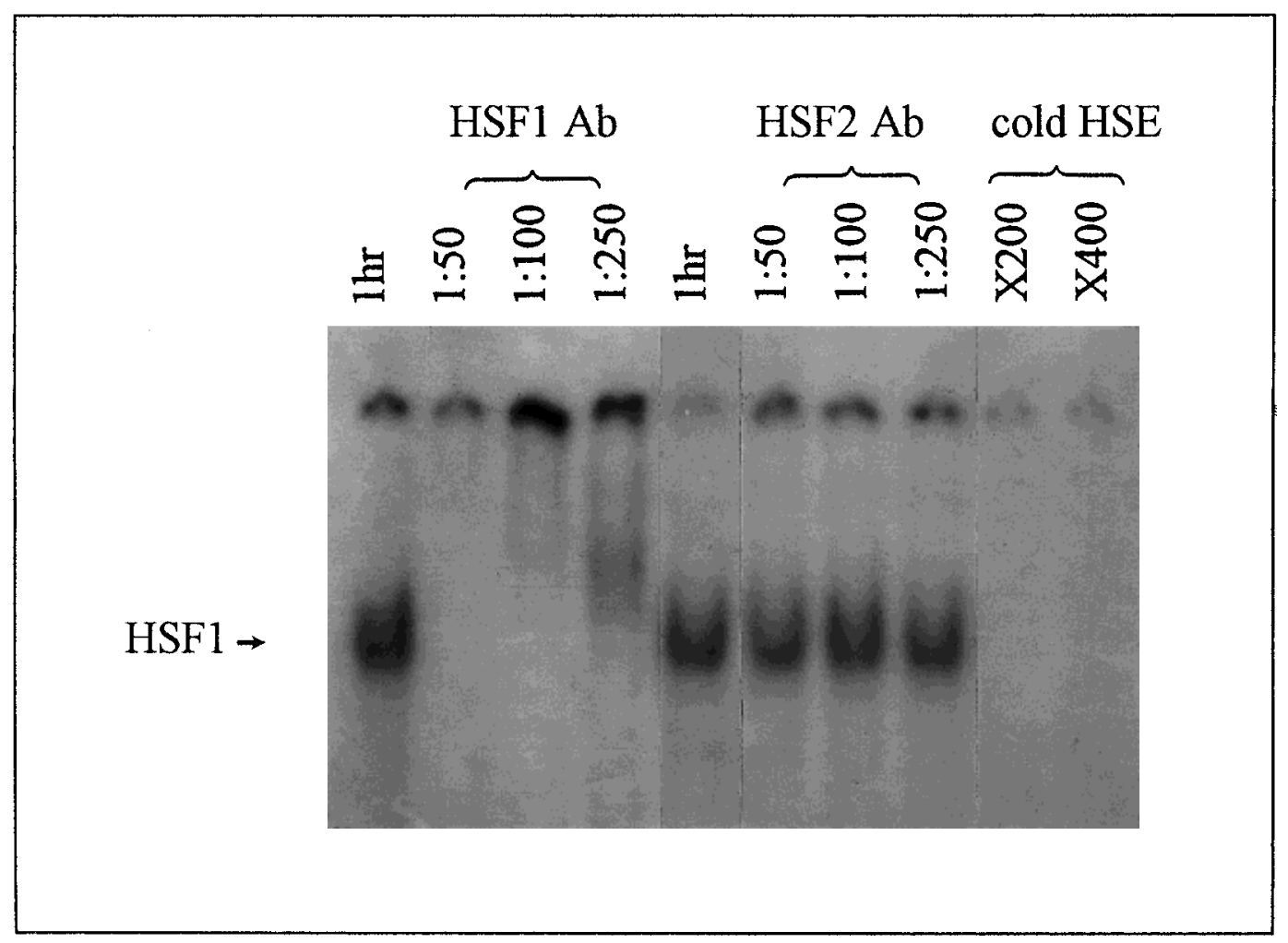

Fig. 6. Characterization of the HSF:DNA complex that is formed with cerebellar extracts from 1-hr hyperthermic animals. Cerebellar extracts from 1-hr hyperthermic animals were preincubated with antibodies specific to either HSF1 or HSF2 at various dilutions (1:50, 1:100, 1:250) before gel-mobility shift analysis. To determine the specificity of the probe, extracts were preincubated with either a 200-fold or 400-fold excess of unlabelled HSE probe (last two lanes). $\mathrm{Ab}$, antibody.

time than the cerebellum to reach maximum temperatures. Similarly, the temperature of the retina may decrease more quickly than that of the cerebellum after reaching a maximum. Thus, the delayed kinetics of the up-regulation of the hsp70 transcription rate in the retina relative to the cerebellum may result from differences in temperature changes. Differences in hsp70 transcriptional profiles between the cerebellum and the retina may also reflect different basal levels of hsp70. Manzerra et al. (1997) showed that the rabbit retina exhibits a basal hsp70 level greater than that of the cerebellum. The presence of high basal levels of hsp70 may delay the onset of induction in the retina, as has been suggested in other reports (Mosser et al., 1993; Baler et al., 1996).

In eukaryotes, transcription of heat-shock genes is mediated by the binding of an HSF1 to HSEs (for review, see $\mathrm{Wu}, 1995)$. This transcription factor is found in a monomeric, non-DNA-binding form under normal conditions (Westwood and Wu, 1993). During stress, HSF1 is activated to a trimeric, DNA-binding form that subsequently induces transcription of heat-shock genes (Baler et al., 1993; Sarge et al., 1993; Sistonen et al., 1994).
Previous studies using cell culture systems have demonstrated a tight correlation between the DNA-binding activity of HSF1 and the transcription rate of hsp70 (Mosser et al., 1988; Abravaya et al., 1991; Sarge et al., 1993). To examine the kinetics of HSF1 binding in rabbit neural regions after hyperthermia, gel-mobility shift assays were performed on tissue extracts obtained from the same animals used in the nuclear run-on analysis.

Gel-shift assays carried out on cerebellar extracts showed induction of HSE-binding activity at $0.75 \mathrm{hr}$ that remained high until $2.00 \mathrm{hr}$ (Fig. 4). Gel-supershift experiments revealed that this activity resulted from binding of HSF1. The activation of HSF1 was similar to the time course of transcriptional induction of hsp70 that was observed in the nuclear run-on analysis. The role of HSF1 as the mediator of stress-induced, heat-shock gene transcription has been well documented (Mosser et al., 1988; Sarge et al., 1993). In the retina, HSE binding reached a maximum at $1.50 \mathrm{hr}$ (Fig. 5). This profile resembled the transcriptional induction profile seen in the retina by run-on analysis. Thus, we are able to correlate two events involved in the expression of heat-shock 


\section{A}

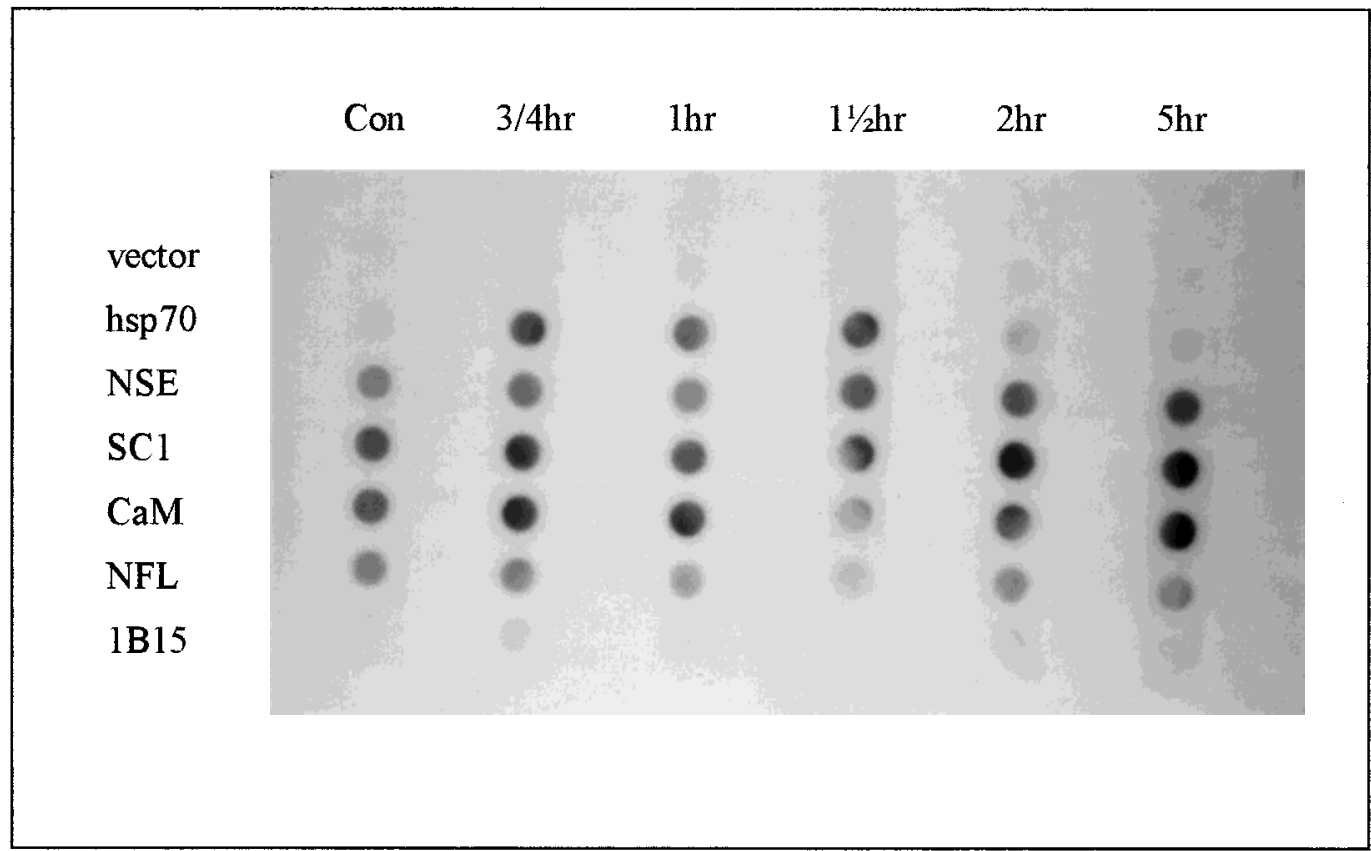

B
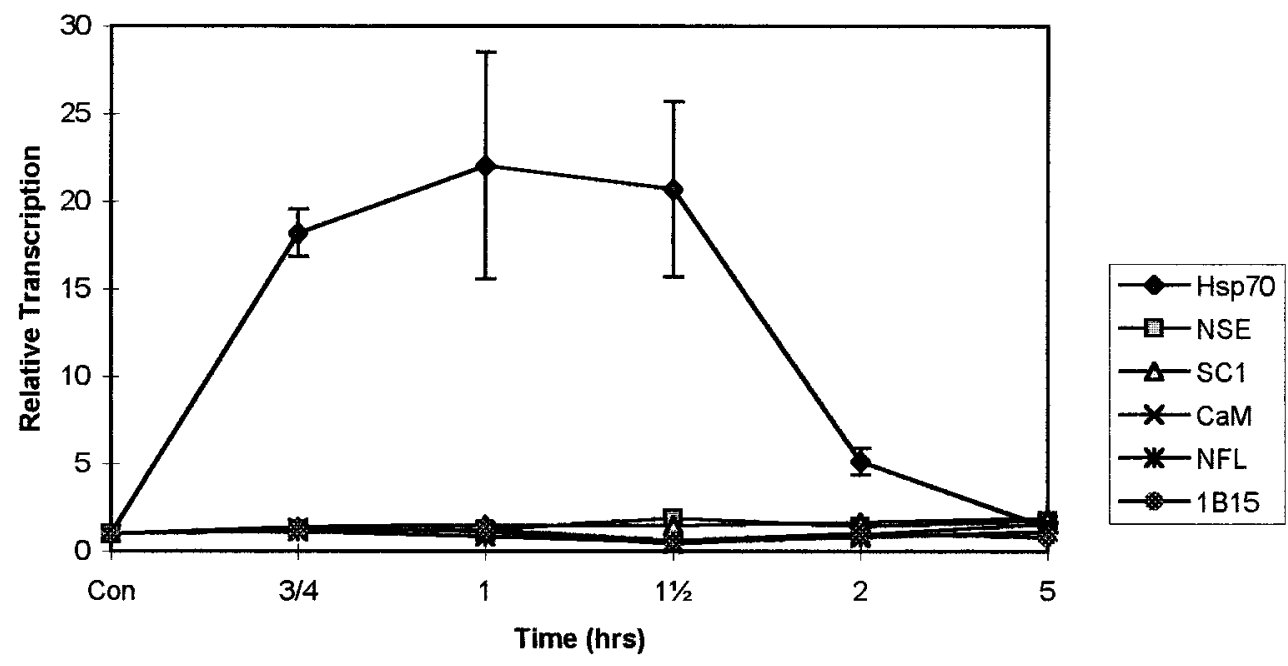

Fig. 7. Transcription of nonheat-shock genes in the cerebellum following hyperthermia. Cerebellar nuclei were isolated at various time points following hyperthermia, and nuclear run-on transcription assays were performed. A: Autoradiogram showing transcription rates of nonheat-shock genes (CaM I, calmodu- lin; NSE, neuron-specific enolase; NFL, neurofilament-L; 1B15, cyclophilin) and SC1, a putative extracellular matrix glycoprotein, as well as hsp70 for comparison. B: Quantitation of transcription levels. Control values (Con) were standardized to 1.0 . 
genes after hyperthermia in vivo: DNA binding of HSF1 and changes in the in vivo transcription rate of hsp70.

The effects of heat shock on the transcription of hsp70 have been characterized extensively in tissue culture systems. Less is known, however, about the effects of heat shock on the transcription of nonheatshock genes. Although heat stress has been shown to alter the splicing process of mRNA transcripts (Yost and Lindquist, 1986), effects on transcription rates of nonheatshock genes have not been characterized in great detail. Therefore, we used nuclear run-on transcription assays to examine the effect of a physiologically relevant temperature increase of $2.5^{\circ} \mathrm{C}$ on the in vivo transcription rates of several nonheat-shock genes: CaM I, NSE, NFL, 1B15, and $\mathrm{SC}$, a putative extracellular matrix glycoprotein. In contrast to hsp70, the transcription rates of CaM I, NSE, NFL, 1B15, and SC1 remained relatively constant during hyperthermia. Thus, a small temperature increase of $2.5^{\circ} \mathrm{C}$ is sufficient to induce a major up-regulation in the transcription rate of hsp70, whereas the transcription rates of other genes are relatively unaffected.

In cell culture systems, heat shock has been shown to reduce the transcription rate of certain nonheat-shock genes. O'Brien and Lis (1993) showed a rapid repression of the histone $\mathrm{H} 1$ gene by heat shock $\left(+15^{\circ} \mathrm{C}\right)$ in Drosophila cells by using nuclear run-on transcription assays. This reduction in transcription was attributed to fewer RNA polymerase molecules on the $\mathrm{H} 1$ gene. Vazquez et al. (1993) reported a progressive decline in the transcription of the actin $5 \mathrm{C}$ gene with increasing temperature during heat shock of Drosophila cells. Transcription of the histone $\mathrm{H} 1$ gene was greatly inhibited by heat shock, whereas transcription of the core histone genes as well as the heat-shock cognate genes only decreased under extreme heat-shock conditions $\left(+13^{\circ} \mathrm{C}\right)$. However, the heat-shock conditions in these systems involved large temperature increases compared with the $2.5^{\circ} \mathrm{C}$ employed in the present study; thus, the transcription rate of nonheat-shock genes may not be affected by a physiologically relevant temperature increase.

\section{ACKNOWLEDGMENTS}

We thank Kevin Sarge (University of Kentucky) and Richard Morimoto (Northwestern University) for donation of the HSF1 and HSF2 antibodies and Lee Weber and Eileen Hickey (University of Nevada) for the hsp90 $\alpha$ and hsp90 $\beta$ cDNA plasmids. This work was funded by grants to I.R.B. from MRC Canada.

\section{REFERENCES}

Abravaya K, Phillips B, Morimoto RI (1991): Attenuation of the heat shock response in Hela cells is mediated by the release of bound heat shock transcription factor and is modulated by changes in growth and in heat shock temperatures. Genes Dev 5:21172127.

Baker MA (1979): A brain-cooling system in mammals. Sci Am 240:130-139.

Baler R, Dahl G, Voellmy R (1993): Activation of human heat shock genes is accompanied by oligomerization, modification, and rapid translocation of heat shock transcription factor HSF1. Mol Cell Biol 13:2486-2496.

Baler R, Zou J, Voellmy R (1996): Evidence for a role of hsp70 in the regulation of the heat shock response in mammalian cells. Cell Stress Chaperones 1:33-39.

Brown IR (1994): Induction of heat shock genes in the mammalian brain by hyperthermia and tissue injury. In Mayer RJ, Brown IR (eds): "Heat Shock Proteins in the Nervous System." London: Academic Press, pp 31-53.

Brown IR, Rush SJ (1990): Expression of heat shock genes (hsp70) in the mammalian brain: Distinguishing constitutively expressed and hyperthermia-inducible mRNA species. J Neurosci Res 25:14-19.

Brown IR, Rush SJ (1996): In vivo activation of neural heat shock transcription factor HSF1 by a physiologically relevant increase in body temperature. J Neurosci Res 44:52-57.

Cosgrove JW, Brown IR (1983): Heat shock protein in the mammalian brain and other organs following a physiologically relevant increase in body temperature induced by LSD. Proc Natl Acad Sci USA 80:569-573.

Cotto JJ, Kline M, Morimoto RI (1996): Activation of heat shock factor 1 DNA binding precedes stress-induced serine phosphorylation. J Biol Chem 271:3355-3358.

Danielson PE, Forss-Petter S, Brow MA, Calavetta L, Douglass J, Milner RJ, Sutcliffe JG (1988): p1B15: A cDNA clone of the rat mRNA encoding cyclophilin. DNA 7:261-267.

Forss-Petter S, Danielson P, Sutcliffe JG (1986): Neuron-specific enolase: Complete structure of rat mRNA, multiple transcription start sites, and evidence suggesting posttranscriptional control. J Neurosci Res 16:141-156.

Foster JA, Brown IR (1996a): Intracellular localization of heat shock mRNAs (hsc70 and hsp70) to neural cell bodies and processes in the control and hyperthermic rabbit brain. J Neurosci Res 46:652-665.

Foster JA, Brown IR (1996b): Differential induction of heat shock mRNA in oligodendrocytes, microglia, and astrocytes following hyperthermia. Mol Brain Res 45:207-218.

Foster JA, Rush SJ, Brown IR (1995): Localization of constitutive and hyperthermia-inducible heat shock mRNAs (hsc70 and hsp70) in the rabbit cerebellum and brainstem by nonradioactive in situ hybridization. J Neurosci Res 41:603-612.

Georgopoulos C, Welch WJ (1993): Role of the major heat shock proteins as molecular chaperones. Annu Rev Cell Biol 9:601634.

Greenberg ME, Bender TP (1992): Identification of newly transcribed RNA. In Ausubel FM, Brent R, Kingston RE, Moore DD, Seidman JG, Smith JA, Struhl K (eds): "Short Protocols in Molecular Biology, 2nd ed." New York: John Wiley and Sons, pp 4.25-4.29.

Hickey E, Brandon SE, Smale G, Lloyd D, Weber LA (1989): Sequence and regulation of a gene encoding a human 89kilodalton heat shock protein. Mol Cell Biol 9:2615-2626.

Johnston IG, Paladino T, Gurd JW, Brown IR (1990): Molecular cloning of SC1: A putative brain extracellular matrix glycoprotein showing partial similarity to osteonectin/BM40/SPARC. Neuron 2:165-176.

Kluger MJ, Gonzalez RR, Stolwijk AJ (1973): Temperature regulation in the exercising rabbit. Am J Physiol 224:130-135. 
Lewis SA, Cowan NJ (1986): Anomalous placement of introns in a member of the intermediate filament multigene family: An evolutionary conundrum. Mol Cell Biol 6:1529-1534.

Lindquist S, Craig EA (1988): The heat shock proteins. Annu Rev Genet 22:631-677.

Lis J, Wu C (1993): Protein traffic on the heat shock promoter: Parking, stalling, and trucking along. Cell 74:1-4.

Manzerra P, Brown IR (1990): Time course induction of a heat shock gene (hsp70) in the rabbit cerebellum after LSD in vivo: Involvement of drug-induced hyperthermia. Neurochem Res 15:53-59.

Manzerra P, Brown IR (1992): Distribution of constitutive- and hyperthermia-inducible heat shock mRNA species (HSP70) in the Purkinje layer of the rabbit cerebellum. Neurochem Res 17:559-564.

Manzerra P, Rush SJ, Brown IR (1993): Temporal and spatial distribution of heat shock mRNA and protein (hsp70) in the rabbit cerebellum in response to hyperthermia. J Neurosci Res 36:480-490.

Manzerra P, Rush SJ, Brown IR (1997): Tissue-specific differences in heat shock protein hsc70 and hsp70 in the control and hyperthermic rabbit. J Cell Physiol 170:130-137.

Mathur SK, Sistonen L, Brown IR, Murphy SP, Sarge KD, Morimoto RI (1994): Deficient induction of human hsp70 heat shock gene transcription in Y79 retinoblastoma cells despite activation of heat shock factor 1. Proc Natl Acad Sci USA 91:8695-8699.

Mayer J, Brown IR (eds) (1994): "Heat Shock Proteins in the Nervous System." London: Academic Press.

Morimoto RI (1993): Cells in stress: Transcriptional activation of heat shock genes. Science 259:1409-1410.

Morimoto RI, Tissieres A, Georgopoulos C (1994): “The Biology of the Heat Shock Proteins and Molecular Chaperones." New York: Cold Spring Harbor Laboratory Press.

Mosser DD, Theodorakis NG, Morimoto RI (1988): Coordinate changes in heat shock element binding activity and hsp70 gene transcription rates in human cells. Mol Cell Biol 8:4736-4744.

Mosser DD, Duchaine J, Massie B (1993): The DNA-binding activity of the human heat shock transcription factor is regulated in vivo by hsp70. Mol Cell Biol 13:5427-5438.

Nakai A, Tanabe M, Kawazoe Y, Inazawa J, Morimoto RI, Nagata K (1997): HSF4, a new member of the human heat-shock factor family which lacks properties of a transcriptional activator. Mol Cell Biol 17:469-481.

Ni B, Rush S, Gurd JW, Brown IR (1992): Molecular cloning of calmodulin mRNA species which are preferentially expressed in neurons in the rat brain. Mol Brain Res 13:7-17.

O'Brien T, Lis JT (1993): Rapid changes in Drosophila transcription after an instantaneous heat shock. Mol Cell Biol 13:3456-3463.

Rabindran SK, Giorgi G, Clos J, Wu C (1991): Molecular cloning and expression of a human heat shock factor, HSF1. Proc Natl Acad Sci USA 88:6906-6910.

Rabindran SK, Haroun RI, Clos J, Wisniewski, J, Wu C (1993):
Regulation of heat shock factor trimerization: Role of a conserved leucine zipper. Science 259:230-234.

Rebbe NF, Hickman WS, Ley TJ, Stafford DW, Hickman S (1989): Nucleotide sequence and regulation of a human $90-\mathrm{kDa}$ heat shock protein gene. J Biol Chem 264:15006-15011.

Saper CB, Breder CD (1994): The neurological basis of fever. N Engl J Med 330:1880-1886.

Sarge KD, Zimarino V, Holm K, Wu C, Morimoto RI (1991): Cloning and characterization of two mouse heat shock factors with distinct inducible and constitutive DNA binding activity. Genes Dev 5:1902-1911.

Sarge KD, Murphy SP, Morimoto RI (1993): Activation of heat shock gene transcription by heat shock factor 1 involves oligomerization, acquisition of DNA-binding activity, and nuclear localization and can occur in the absence of stress. Mol Cell Biol 13:1392-1407.

Sarge KD, Park-Sarge O, Kirby JD, Mayo KE, Morimoto RI (1994): Expression of heat shock factor 2 in mouse testis: Potential role as a regulator of heat-shock protein gene expression during spermatogenesis. Biol Reprod 50:1334-1343.

Schuetz TJ, Gallo GJ, Sheldon L, Tempst P, Kingston RE (1991): Isolation of a cDNA for HSF2: Evidence for two heat shock factor genes in humans. Proc Natl Acad Sci USA 88:6911-6915.

Sistonen L, Sarge KD, Morimoto RI (1994): Human heat shock factors 1 and 2 are differentially activated and can synergistically induce hsp70 gene transcription. Mol Cell Biol 14:2087-2099.

Tytell M, Barbe MF, Brown IR (1994): Induction of heat shock (stress) protein 70 and its mRNA in the normal and light-damaged rat retina after whole body hyperthermia. J Neurosci Res 38:19-31.

Vazquez J, Pauli D, Tissières A (1993): Transcriptional regulation in Drosophila during heat shock: A nuclear run-on analysis. Chromosoma 102:233-248.

Watowich SS, Morimoto RI (1988): Complex regulation of heat shock-and glucose-responsive genes in human cells. Mol Cell Biol 8:393-405.

Welch WJ (1992): Mammalian stress response: Cell physiology, structure/function of stress proteins, and implications for medicine and disease. Physiol Rev 72:1063-1081.

Westwood JT, Wu C (1993): Activation of Drosophila heat shock factor: Conformational change associated with a monomer-totrimer transition. Mol Cell Biol 13:3481-3486.

Wu B, Hunt C, Morimoto RI (1985): Structure and expression of the human gene encoding major heat shock protein hsp70. Mol Cell Biol 5:330-341.

Wu C (1995): Heat shock transcription factors: Structure and regulation. Annu Rev Cell Dev Biol 11:441-469.

Xia W, Voellmy R (1997): Hyperphosphorylation of heat shock transcription factor 1 is correlated with transcriptional competence and slow dissociation of active factor trimers. J Biol Chem 272:4094-4102.

Yost HJ, Lindquist S (1986): RNA splicing is interrupted by heat shock and is rescued by heat shock protein synthesis. Cell 45:185-193. 